\title{
APONTAMENTOS À FORTUNA CRÍTICA de IL PRINCIPE, de MACHIAVELLI: DE GENTILLET A GRAMSCI E A RECEPÇÃO BRASILEIRA
}

\author{
Appointments about the critical fortune of Machiavelli's il principe: from \\ Gentillet to Gramsci and the brazilian reception
}

\section{Antonio José Romera Valverde PUC-SP}

Para Francisco Benjamin de Souza Netto (1937 - 2019), in memoriam.

"DIRÁ MAQUIAVEL: [...] qual o objetivo dos livros, senão o de ensinar a vivier? [...] O meu livro é e será sempre o código do real, único, infalível e universal modo de viver; e por isso, sempre celebradíssimo mais pela ousadia, ou melhor, pela coerência por mim usada ao escrevê-lo do que pela necessidade de pensar muito e dizer o que todos sabem, veem ou fazem." (Giacomo LEOPARDI, "Para o Conto 'Xenofonte e Maquiavel", 1996, p. 464.) ${ }^{1}$

\begin{abstract}
Resumo: O ensaio roteiriza e analisa a fortuna crítica de Il Principe (1513), de Machiavelli, inscrito sob a tradiçăo humanística do gênero specula principum, - fortuna, antecipadamente, circunscrita por quinze livros do gênero, escritos entre 1402 e 1505, em Itália -. Na sequência, agencia apontamentos acerca da fortuna crítica do livrinho maquiaveliano de Gentillet até Gramsci, com destaque para a sua presença em França, Inglaterra, Holanda, Alemanha, Itália. Ao final, o ensaio analisa a recepção brasileira a Machiavelli.
\end{abstract}

Palavras-chave: Machiavelli; Il Principe; fortuna crítica; specula principum; Gentillet; Gramsci; pensamento político brasileiro.

\begin{abstract}
The essay follows and analyzes the critical fortune of Machiavelli's Il Principe (1513), fited in the humanistic tradition of the specula principum genre - fortune, in advance, circunscribed by fifteen books of the genre, written in Italy between the years 1402 and 1505 . Following that, it makes appointments about the critical fortune of the Machiavellian book from Gentillet to Gramsci, with enphasis on its presence in France, England, Netherlands, Germany and Italy. At the end, the essay analyzes the reception of Machiavelli's work in Brazil.
\end{abstract}

Keywords: Machiavelli, Il Principe, critical fortune, specula principum; Gentillet, Gramsci; Brazillian political thought.

Antecedido de quinze livros do gênero specula principum escritos entre 14021403 e 1505, de autores italianos, o "livrinho" De Principatibus ou II Principe, de Maquiavel, de 1513, em verdade, pertencente também ao gênero da tratadística, e encerra a tradição, que remonta à Antiguidade, a Aristóteles, - de anotações desaparecidas - ao tempo em que foi preceptor de Alexandre Magno. E em escritos do mesmo gênero como De Clementia, de Sêneca, dedicado a Nero, em que se lê:: "I.1. Dispus-me, a escrever a

${ }^{1}$ LEOPARDI, G. "Opúsculos Morais", tradução Vilma Barreto de Souza, In Poesia e Prosa organização e notas de Marco Luchesi, Rio de Janeiro, Nova Aguilar, 1996, pp. 309-466. 
respeito da clemência, ó Nero César, para que eu, de certa forma, desempenhasse a função de espelho ${ }^{2}$ e te mostrasse a tua pessoa como a que há de vir para a maior de todas as satisfações (voluptatem maximam omnium). Pois, ainda que o verdadeiro proveito das ações esteja em tê-las realizado corretamente e nenhuma recompensa digna das virtudes seja nada além das próprias virtudes, é bom inspecionar e andar às voltas com a boa consciência ${ }^{3}$ e, depois, lançar os ollhos sobre esta imensa multidão discordante, sediciosa e descontrolada - pronta para se precipitar igualmente para a sua perdição como para a alheia, se romper o seu jugo - e falar consigo mesmo palavras deste teor: 2. 'será que por acaso eu, entre todos os mortais, agradei e fui eleito 4 para desempenhar na terra o papel dos deuses? Eu sou o árbitro de vida e de morte desta gente. Está em minhas mãos a qualidade da sorte e da posição que cabe a cada pessoa. Por minha boca, a Fortuna anuncia o que deseja que se reserva a cada mortal' (SÊENECA, 1990, pp. 39-40), ${ }^{n 5}$

Porém, o opúsculo de Maquiavel, ao menos em tese, liquida a tradição do gênero specula principum, sobremaneira, pelo extraordinário realismo acerca da (im)previsível e, ao mesmo tempo, calculada ação política do novíssimo tipo social, em movimento ao tempo do Renascimento: o príncipe. Mesmo que outros pensadores continuassem a escrever espelhos aos príncipes, como o de Erasmo de Rotterdam, Da educação do príncipe cristão, de 1516, pautado pelo pensamento de Xenofonte, dedicado ao Príncipe Carlos, futuro imperador Carlos V. - Sob o arco do mercantilismo.

A título de contextualização literário-político de ordem histórica, eis os autores, títulos e destinatários, com suas respectivas idades, dos quinze livros que antecederam, cronologicamente, a fortuna crítica do de Maquiavel:

1402-1403, Pier Paolo Vergerio, De Ingenuis Moribus per Ubertino da Carrara, 12 e 13 anni;

1435-1436, Catone Sacco, Semideus per Filippo Maria Visconti, 43 e 44 anni;

1443, Enea Silvio Piccolomini, Lettera a Sigismondo del Tirolo, 16 anni;

1450, Enea Silvio Piccolomini, De Liberorum Educatione per Ladislao V di Hungheria, 10 anni:

1454 (dopo il), Michele Savonarola, Del Felice progresso di Borso d'Este, più di 41 anni;

1464-1465, Giovanni Pontano, De príncipe per Alfonso II d'Aragona, 16 e 17 anni:

1465-1470, Bartolomeo Platina, De príncipe per Federico Gonzaga, 24 e 25 anni;

1472, Diomede Carafa, De regentiis et boni principis officiis per Eleonora d'Aragona, 22 anni;

1476, Diomede Carafa, De institutione vivendi per Beatrice d'Aragona, 19 anni;

1479, Francesco Filelfo, Intituctione del ben vivere utilissima per Filiberto di Savoia, 14 anni;

1481, Francesco Filelfo, Lettere a Giovanni Sforza, 13 anni;

1484, Franceso Patrizi, De regno et regis institione per Alfonso II d'Aragona, 36 anni;

1497, Filippo Beroaldo il vecchio, De optimo statu et príncipe per il polacco Paulus Sidlovitiu, alias Pawel Szydlowiecki, 19 anni;

\footnotetext{
${ }^{2}$ Mesmo que a literatura anterior tenha se perdido, "O príncipe-espelho pressupõe o espelho do príncipe. Sêneca, no De Clementia composto para o jovem Nero, utiliza a imagem do speculum nesse sentido (SENELLART, 2006, p. 50)."

${ }^{3}$ Sêneca reproduz na passagem referida o hábito estoico de proceder, diariamente, a um exame de consciência acerca dos feitos (do dia). O próprio conservou tal hábito por toda vida.

${ }^{4}$ Assim, "para "transformar um impetus em habitus animi" (SENELLART, 2006, p. 51), em Cartas a Lucilio, Livro II , 16, 6, Sêneca completa a assertiva acerca da eleição: "Agora regresso ao meu ponto de partida: aconselhar-te com todo o empenho que nunca deixes esmorecer ou esfriar o ímpeto que te vai na alma. Conserva-o, dá-lhe forma, de modo a que esse ímpeto de hoje se torne configuração permanente de tua alma (SÉNECA, III, 16, 6, 2004, p. 56)."

${ }^{5}$ Para Senellart, os "espelhos [...] foram inventados para permitir ao homem conhecer-se. Mas há, nesse tratado, uma perfeita circularidade entre o príncipe, o espelho e o modelo de virtude que ele reflete. Este não é senão o próprio Nero ('ninguém te busca um modelo [exemplar] fora de ti mesmo'), convidado a contemplar não o espetáculo de seus vícios ou de suas fraquezas para corrigi-las, ou o retrato de um imperador ideal para imitálo, mas sua própria excelência. Para que serve, [....], exortá-lo à mansuetude se ele já possui essa virtude no mais alto grau? (SENELLART, 2006, p. 51)."
} 
1505, Antonio Galateo de Ferrariis, De educatione, dedicato a Crisostomo Colonna, per il príncipe Ferdinando d'Aragona, 17 anni, figlio di Federico I di Napoli. ${ }^{6}$

Como hipótese, dentre os escritos políticos de Maquiavel, ao tempo em que respondeu pela Segunda Secretaria de Florença, datados de 1499 a 1512, conforme estudo excelente de J. J. Marchand, provavelmente o escrito "Ghiribizzi al Soderini" possa ser considerado uma antecipação de Il Principe.7 A polêmica remete a carta enviada por Maquiavel, da Perugia, onde esteve entre 13 e 21 de setembro de 1506, período em que acompanhou a missão de Júlio II para a reconquista do território papal. En verdade, trata de um esboço de resposta à missiva de Giovan Battista Soderini, sobrinho do gonfalonieiro Pier Soderini, datada de 12 de setembro de 1506, acerca da fortuna na política e de análise do modo de proceder de um político, no caso, o próprio papa Júlio II. ${ }^{8}$ Capata ressalta que a carta é o divisor de águas entre "la fase della Cancelleria e quella post res perdita". Ao que acrescenta: "almeno per quanto riguarda i fondamenti antropologici del pessimismo machavelliano (CAPATA, 2013, p. 97).".9

Contudo, a fortuna crítica da obra maquiaveliana, a rigor, principia com o plágio de Il Principe, por Agostino Nifo, ${ }^{10}$ intitulado De regnandi peritia, publicado em 1523 , pela tipografia dei Giunti, antes mesmo da publicação impressa da obra plagiada, em 1532. ${ }^{11}$ Nifo, filósofo e médico, de Sessa (Sessa Aurunca), discípulo de Nicoletto Vernia, estudioso de Aristóteles e de Averrois, muito jovem se tornara professore straordinario da cátedra de Filosofia, da Universidade de Pádua, ensinando também em Pisa. Contestou a tese de Pomponazzi acerca da imortalidade da alma. E o feito suspeito: Nifo decidiu assinar Il Principe, de Maquiavel em tradução para o Latim, a língua universal da comunicação "científica" da época. Contudo, sob a forma reordenada da matéria tratada pelo Florentino, com critério lógico e classificatório próprio do aristotelismo, eliminando os três últimos capítullos do original. Larrivaille, recentemente, apontou a questão acerca da dificuldade de compreender o significado da propriedade autoral ao tempo do Renascimento. Pois, no trabalho de reescrita, Nifo consta como tradutor da obra, desconsiderando as alterações operadas por ele. Há quem reconheça méritos na transcrição de Nifo (BORRELLI, 2013, pp. 271-273).

Il Principe e Discorsi sopra la prima deca de Tito Livio foram publicados primeiramente em Roma, entre 1531-1532, sob a proteção da Sé Apostólica, contendo o imprimatur papale, a autorização de estampar os textos e, mais ainda o privilegio di stampa, concessão do Pontífice para obra considerada meritória de seu favor. Todavia, a situação mudou prontamente, e as obras foram incluídas nos registros do Index Librororum Prohibitorum, de Paulo IV, (Giovvani Pietro Carafa), publicado em 1559, de

\footnotetext{
${ }^{6}$ PEDULLÀ, Gabrielle, "Prima del Principe: la tradizione umanistica degli specula principum", In Il Principe di Niccolo Machiavelli e il suo tempo, 1513-2013, a cura de Alessandro Campi et alii, Roma, Treccani, 2013, pp.8384.

${ }^{7}$ Conferir CAPATA, Alessandro, "I Ghiribizzi al Soderint un'anticipazione del Principe?", In Il Principe di Niccolò Machiavelli e il suo tempo, 1513-2013, a cura di Alessandro Campi et alii, Roma, Treccani, 2013, pp. 97 100. Ver também comentadores referidos nas notas 1, 2 e 3, da p. 97 do texto de Capata.

${ }^{8}$ A propósito, conferir MACHIAVELLI, N., "Lettere", In _ Opere, volume terzo, lettera 119, 12 settembre 1506, 1984, pp. 237-238.

${ }^{9}$ Idem, p. 97.

${ }_{10}$ A propósito, Ridolfi registrou o contexto de preocupaç̃es de Maquiavel ao final de 1522 e princípio de 1523: "Torna a sentir na carne as torturas, e na alma o encarceramento ocorrido sob a acusação de ter tomado parte numa conjura contra outro cardeal da familia Medici, considera desconsoladamente aqueles últimos anos passados, aquele período de sua vida 'posto em meio a duas conjuras': precisamente como ao início do oitavo livro de História de Florença, para o qual no fim daquele ano, e no início de 1523 , já devia estar se aproximando do término. Para colmar seu amargo cálice, nesse momento foi impresso o famoso e infame plágio de Agostino Nifo, uma torpe falsificação de O Príncipe (RIDOLFI, 2003, pp. 234-235)." Conferir também a nota n. 23, relativa à passagem supracitada, In RIDOLFI, 2003, p. 427.

${ }^{11}$ Apud LARIVAILLE, Paul et PERNET-BREAU, Simone, Une réécriture du Prince de Machiavel. Le De regnandi peritia de Agostino Nifo, Paris, 1987 (reimpression d'Agostino Nifo, De regnandi peritia, Naples, 1523, avec as traduction française). Conferir também BORRELLI, Gianfranco, "Agostino Nifo e il plagio del Principe", In Machiavelli. Enciclopedia machiavelliana, a cura di Gemaro Sasso, Roma, Treccani, s.d., pp. 271-273.
} 
forma definitiva, que proibia os católicos de lerem a obra do Florentino. ${ }^{12}$ Sanção confirmada em 1564 pela Comissão encarregada da revisão das interdições, nomeada pelo Concílio de Trento. A alegação para proibiçãa da circulação das obras se deve ao registro da crítica ao Cristianismo, - a religião moderna, como quer Maquiavel -, que enfraquecera os homens, em contraponto à valoração militar de homens fortes, sobremaneira dos romanos antigos.

Porém, é mister ressaltar que os familiares dos Medici - justapostos à hierarquia eclesiástica - viam com ollhos razoáveis as análises maquiavelianas. Vez que, - ao tempo da crise sucessória do poder mediciano, iniciada em 1519 com a morte Lorenzo, duque de Urbino, falecido a 04 de maio do mesmo ano -, por iniciativa do cardeal Júlio, em audiência do 10 de março de 1520 , encomendou-se a Maquiavel um projeto novo de governo para Florença. Trabalho executado, Maquiavel escreveu "Discurso sobre as formas de governo de Florença após a morte do jovem Lorenzo de Medici" (Discursus florentinarum rerum post mortem iunioris Laurentii Medices) (MACHIAVELLI, Opere, II, pp. 205-222), endereçado ao papa Leão X e ao cardeal Júlio, ambos Medici. O discurso trata das graves dificuldades relativas ao regime político da República de Florença, em curso há séculos. Pois, Florença não conseguira ser nem principado nem república, de modo e de sentido próprios e estritos. Em seguida, o papa Clemente VII (1478-1534) encomendou a Maquiavel a pesquisa de documentos históricos e a escrita do que viria a ser História de Florença, talvez o texto mais árido, também o mais rigoroso do Florentino. Encerrada a narrativa histórica em 1492, ao momento da morte de Lorenzo de' Medici, o Magnífico, tendo podido prosseguir a análise, porém, como quer Maquiavel a verdade ofende muita gente, - no caso, gente ainda viva. Obra dedicada ao papa Clemente VII. ${ }^{13}$

A fortuna crítica prossegue em França com a publicação de Discours sur les moyens de bien gouverner (L'Anti-Machiavel), do calvinista tido como moderado, Innocent Gentillet, de 1576, a responsabilizar Maquiavel como mentor remoto do massacre da Noite de São Bartolomeu, em Paris. Afinal, o Florentino dedicara Il Principe a Lorenzo de' Medici, neto de Lorenzo, o Magnífico, e, (aquele), pai de Catarina de' Medici, que viria a ser rainha consorte de França, casada com Henrique II de Valois, mãe da rainha Margarida de Valois (1553-1615). À sua vez, casada com o calvinista Henrique IV de Navarra, também conhecido como Henrique III de França, - tão bem caracterizado por Heinrich Mann em romance homônimo, Henrique $I V^{14}$ Catarina recebera a alcunha de "discípula de Maquiavel", pois, ela e o filhos, em particular o filho d'Anjou ${ }^{15}$ armaram o massacre dos calvinistas durante o Massacre de São Bartolomeu, ocorrido nos dias 23 e 24 de agosto de 1572. Em verdade, o mote prosaico da obra de Gentillet é a conlhecida passagem de Maquiavel, em que sugere ao príncipe realizar o mal de uma só vez e o bem a conta gotas. Assim, os efeitos e os ganhos políticos seriam duradouros. Eis a intriga, a la Noel Rosa, que nasce de um café pequeno, que se toma para se ver quem vai pagar! Ou como de um ressentimento de caráter político-religioso nasce a contestação por suposta consequência política, em vista de posição prescritiva da ação política duradoura.

O livro de Gentillet compõe-se de comentários e de reflexões de caráter políticoreligioso, desde uma máxima ou resumo destacados, ao todo cinquenta, no geral, extraídas de passagens de II Principe ou dos Discorsi, seguidos de análise, que, segundo

${ }^{12}$ Conferir FRAJESE, Vittorio, "Index librororum prohibitorum", In Machiavelli. Enciclopedia Machiavelliana, vol. II, a cura di Gennaro Sasso, Roma, Treccani, 2014, pp. 12-17.

${ }^{13}$ Eis a dedicatória: "Al Santissimo e Beatissimo Padre Signore Nostro Clemente Settimo lo Umile Servo Niccolò Machiavelli (MACHIAVELLI, "Istorie Fiorentine", In —— Opere, volume secondo, 1971, p. 277)." Maquiavel recebera do ainda cardeal Giulio de' Medici a encomenda de escrevê-la, aos 08 de novembro de 1520. Os oitos livros de Istorie Fiorentine entregues em 1525, pelo que teria recebido cento e vinte ducados de ouro, segundo Ridolfi.

${ }^{14}$ MANN, H., A Juventude do Rei Henrique IV, tradução Lya Luft, São Paulo, Ensaio, 1993. A propósito, conferir o "Capítulo IV - Margot", acerca da pessoa / personagem, da armação do massacre e o assassinato do almirante Coligny, pp. 222-231. A alcunha de rainha Margarida, la reine Margot, foi criada por Alexandre Dumas, pai.

1515 "Hercule-François, duc d'Alençon, sixième fils d'Henri II et Catherine de Médicis (1554-1584), prit le titre de duc d'Anjou après le couronnement d'Henri III (RATHÉ, In GENTILLET, 1968, p. 19, n. 1)." 
Mukabi Pierre nem sempre trata de modo fidedigno a matéria proposta (PIERRE, 2005, p. 7). O Anti-Machiavel divide-se em três partes: a primeira cuida dos conselheiros do príncipe; a segunda, da religião e a terceira, da prática diária das coisas de Estado. Gentillet atrela política à administração da coisa pública, de modo a opor-se ao sentido inovador da expressão "razão de Estado". Para o Calvinista, o poder real deve fundar-se na crença em Deus, nos costumes e na lei moral. Vê-se por que flancos pretendeu demolir o realista pensamento maquiaveliano. ${ }^{16}$ Como Maquiavel ao final de Il Principe, Gentillet encerra o Anti-Machiavel também de modo exortativo, com um poema intitulado "Soulhait pour la France" (GENTILLET, 1968, pp. 635-636).

No século XVIII, o verbete relativo ao Florentino da Enciclopédia, ou Dicionário razoado das ciências e dos ofícios, de todo negativo, não se emparelha com as assertivas de Rousseau, em Contrato Social ou Princípios do Direito Político, de 1762. Ao volume quarto da Enciclopédia é dedicado à Política, o verbete "Maquiavel (História da Filosofia)", de Diderot [9, 793], que define: "Maquiavelismo é uma espécie de política detestável que se pode definir em duas palavras: é a arte de tiranizar, cujos princípios Maquiavel difundiu em suas obras. [...] Há poucas obras que fizeram tanto barulho quanto o tratado do príncipe. É nele que Maquiavel ensina aos soberanos a desprezar a religião, as regras de justiça, a santidade dos pactos e tudo o que há de sagrado, quando o interesse exigir. Os capítulos 15 e 25 poderiam ser chamados de circunstâncias nas quais convém ao príncipe ser um criminoso." Diderot prossegue afirmando: "Como explicar que um dos mais ardentes defensores da monarquia tenha se tornado de repente um infame apologista da tirania?" Com a ressalva de que quando "Maquiavel escreveu seu tratado do príncipe, é como se ele dissesse aos seus concidadãos: "leiam bem esta obra. Se alguma vez aceitarem um senhor, ele será tal como o descrevo; eis a besta feroz à qual vós vos entregareis'. Assim, se seus contemporâneos ignoraram seu objetivo, a cullpa é deles. Viram a sátira como um elogio (DIDEROT, 2015, pp. 230-231)." Diderot parece antecipar o registro de Rousseau, como se verá adiante. Em todo verbete não há referência aos Discorsi, em que se analisa o regime republicano como único capaz de dar estabilidade política, desde a explicitação dos conflitos políticos, que são naturais, e sua transformação em ordenações republicanas.

Maquiavel, pode ser considerado uma das fontes e das influências de Rousseau, em particular pelos Discorsi, seguida de II Príncipe e da Istorie Fiorentine, e de outras obras maquiavelianas, em menor escala. Maquiavel influenciara na elaboração de alguns conceitos rousseaunianos, quando não diretamente referido, fornecendo substrato teórico para tal. Além do Genebrino se contrapor à leitura equivocada de Il Principe, como no caso da nada sutil discordância da interpretação proposta em (o) AntiMaquiavel, de Frederico II, cujo posicionamento contrário aparece na "Apresentação" do Livro I, do Contrato Social, em que se lê: "Entro na matéria sem demonstrar a importância de meu assunto. Perguntar-me-ão se sou príncipe ou legislador, para escrever sobre política. Respondo que não, e que por isso escrevo sobre política. Se fosse príncipe ou legislador, não perderia meu tempo, dizendo o que deve ser feito; haveria de fazê-lo, ou calar-me (ROUSSEAU, I, 1973, P. 27)." Até a explicitação do reconhecimento da relevância da obra maquiaveliana: "Fingindo dar lições aos reis, deu-as, grandes, ao povo. O Príncipe de Maquiavel é o livro dos republicanos (ROUSSEAU, III, VI, 1973, p. 95)." A advertência é endereçada aos homens livres ou em processo de emancipação, sob o contexto hisistórico-filosófico do Esclarecimento.

Ainda no século XVI, a recepção inglesa da obra maquiaveliana fora antecipada por traduções extraoficiais de sua parte mais expressiva, que teriam sido conhecidas por Henrique VIII, conforme Nilo Reis. ${ }^{17}$ Além de referências dos dramaturgos ingleses às passagens de Maquiavel, e do registro de Shakespeare ao identificá-lo como "Old Nick",

${ }^{16}$ Da "Table des matières", se lê: "Epître; Indice de Maximes; Première Partie; Seconde Partie; Trouxième Partie e Souhait pour la France (GENTILLET, 1968, p. 637)."

17 Conforme Nilo Henrique Neves dos Reis, A recepção maquiaveliana em solo britânico: David Hume, leitor de Maquiavel, relatório de estágio de pós-doutorado, realizado na PUC-SP, 2017. 
querendo dizer o "Velho Diabo". Em verdade, sob efeitos da riqueza, Shakespeare parece encenar Maquiavel, ao trocar o trono de Deus medieval, em crise registrada através da denúncia crítica do Florentino, pelo trono de sangue do poder, exemplarmente, nas peças teatrais Macbeth, Hamlet, A tempestade, Ricardo II, Ricardo III. Antecedidos por Christoper Marlowe, - dramaturgo, autor de The Tragical History of Doctor Faustus, a lenda medieval germânica transformada em peça teatral, escrita entre 1588 e $1589-18$ que, para o "Prólogo" da peça Hebreu de Malta, escreveu um poema, cujo primeiro verso pretende identificá-lo: "Eu sou Maquiavel" . ${ }^{\prime 9}$

Após, fora registrado por Bacon nos Essays, da segunda edição de 1625, como nos ensaios: "XIII - Da bondade civil e da bondade natural"; "XV - Das sedições e dos tumultos" e "LVIII - Da vicissitude das coisas", em que se refere nominalmente a Maquiavel. E nos capítulos: "XIX - Do império"; "XX - Do conselho"; "XXIX - Da verdadeira grandeza dos reinos e das repúblicas"; "XXXVI - Da ambição"; "XXXVIII - Da natureza do homem"; "XI - Da fortuna" e "LI - Das facções", em que há umm substrato teórico retirado das obras maquiavelianas, em diálogo sem referência. Também a concepção de religiăo civil, como indicada em A Nova Atlântida, inspirou-se em passagens maquiavelianas da crítica à moderna religião, o cristianismo. Exposta entre os capítulos X e XVI, do Livro Primeiro, dos Discorsi. Porém, certamente, sem adentrar os espectros do ateísmo ou da incredulidade, como concluira Lucien Febvre para tempos próximos passados ${ }^{20}$

${ }^{18}$ Digressão. À "Cena 9" de A Trágica História do Doutor Fausto, Marlowe faz adentrar o Imperador Carlos V, "o Sol que nunca se põe", tomado personagem, que se dirige a Fausto: "Dizem que trazes contigo um espírito através do qual podes realizar o que quiseres. Esta, portanto, é minha solicitação: que me faças ver alguma prova de tua habilidade. Que meus olhos testemunhem o que meus ouvidos escutaram." O Imperador, suspeitando que os herdeiros dele não terão a glória dos antepassados, pede para ver Alexandre, o Grande, “Ícone maior da glória do mundo. O brilho de seus atos grandiosos / Tlumina este mundo com seus raios, / [....] Puderes erguê-lo das criptas ocas / Onde jaz esse ilustre soberano / E trouxeres com ele sua amada, / [ .o. $] \mathrm{Tu}$ satisfarás meu justo desejo / E me fará louvar-te enquanto eu viva. / [...] Adiante, Senhor Doutor, que eu os veja imediatamente. / Entra Mefastófilis com Alexandre e sua Bem-Amada. / (Ao que o Imperador afirma) Realmente, estes não são espíritos, mas a verdadeira substância dos corpos daqueles dois príncipes falecidos (MARLOWE, 2018, pp. 161, 163, 165)."

${ }^{19}$ Eis o poema: "I am Machewill / And weigh not men, and therefore not mens words: / Admir'd I am of those that hate me most. / Though some speake openly against um bookes, / Yet will they reade me, and thereby attaine / To Peters Chayre: And when they cast me off, / Are poyson'd by my climing followers. / I count Religion but a childish Toy, / And hold there is no sinne but Ignorance (MARLOWE, 'Prologue', The Jew of Malta, de 1589), In Il Principe di Niccolo Machiavelli e il suo tempo, 1513-2013, a cura de Alessandro Campi et alii, Roma, Treccani, 2013, p.187.)" Segundo Alessandra Petrina: "Educato a Cambridge, amico di lettori di Machiavelli come Gabriel Harvey e Philip Sidney, e forse lui stesso lettore di Machiavelli. Marlowe è bem cônscio della distanza che existe tra la figura storica dello scrittore fiorentino e la sua caricatura teatrale, $\mathrm{m}$ aquesto non gli impedisce di creare uma straordinaria commistione tra letteratura alta e bassa, venendo encontro ai desideri del pubblico nella sua creazione. In queste poche righe ritroviano l'essenza dela lettura popolare di Machiavelli nell'Inghilterra elisabettiana: la misantropia, la polemica anticatólica, l'ateismo esibito spudoramente (PETRINA, "Machiavelli in Inghilterra e Scozia", In Il Principe di Niccolò Machiavelli e il suo tempo, 1513-2013, a cura de Alessandro Campi et alii, Roma, Treccani, 2013, p. 188)." Marlowe fora acusado de ateísmo, heresia, falsificação, assassinato, - transformado em "figura de uma espécie de monstro moral", contudo, jamais condenado. A propósito, conferir Lús Bueno, "O Nascimento de um Mito Literário", In MARLOWE, 2018, pp. 14, 16-17. - Ateísmo ou blasfêmia? Pois, ao estudar "a religião de Rabelais", Lucien Febvre apontara para a incredulidade e não o ateísmo, durante a primeira metade do século XVI. A propósito, conferir "Crença ou incredulidade" e "Os limites da incredulidade no século XVI", In FEBVRE, 2009, pp. 213-288 e pp. 289-385.

${ }^{20}$ Talvez como o episódio fabuloso da cristianização milagrosa da illha de Bensalem ("A fillha da salvação", em árabe), descrito por Bacon, vinte anos após a ascensão de Jesus aos céus, a população viu no mar um espetácullo luminotécnico, aproximaram e viram um pilar com uma cruz imensa. Aproximaram-se mais e a cruz se desfez, ficando somente uma pequena embarcação, com um livro que continha o Antigo e o Novo Testamentos, - mesmo antes de terem sido escritos, como o Apocalypse e outros -, e uma carta. A carta trazia a mensagem de Bartolomeu, catequizador da Índia: "Eu, Bartolomeu, servo do Altíssimo, e apóstolo de Jesus Cristo, fui avisado por um anjo, que me apareceu numa visão de glória, que deveria confiar esta arca às ondas do mar. Por conseguinte, declaro e dou fé de que o povo ao qual segue o cofre, por ordem de aventurança do Pai e do Senhor Jesus Cristo. Ocorreu com ambos os escritos, tanto o livro e a carta, um grande milagre, como aquele dos apóstolos, no primitivo Dom das Línguas. Pois havendo, a este tempo, nesta terra, hebreus, persas e indianos ao lado de nativos, todos leram o livro e a carta, como se tivessem sido escritos em sua própria língua. E desse modo esta terra foi salva da infidelidade (como parte do mundo antigo o foi da água) por uma arca, 
Em Holanda, em 1589, Justus Lipsius, em Política, acusa Maquiavel de imoralidade, ao passo que no meio acadêmico a acusação recai sob a capa de ateísmo e de oportunismo. Contudo, a primeira tradução do opúsculo data de 1615, editada por um anônimo. Há fortes indícios de que Espinosa inspirou-se em Maquiavel ${ }^{21}$ para a escrita do Tratado Político, - obra inconclusa -, pois está traspassado do pensamento político maquiaveliano, ora explícito, na forma elogio e reconhecimento, como ao nomeá-lo por "prudentíssimo" e "agudíssimo". Com efeito, no Tratado Político, Espinosa escreve: "Os meios, porém, de que deve usar um príncipe que se move unicamente pelo desejo de dominar para poder fundar e manter um estado, mostrou-os o agudíssimo Maquiavel desenvolvidamente, embora não pareça bastante claro com que fim. [...] Além disso, ele quis talvez mostrar quanto uma multidão livre deve precaver-se para não confiar absolutamente a sua salvação a um só [...]. $\mathbb{E}$ sou tanto mais levado a crer isto deste homem prudentíssimo quanto consta ele ter sido pela liberdade, para cuja defesa deu conselhos muito salutares."22 Mas, a expansão da assimilação parece refletir em interconexões com a Ética, de Espinosa. Para além da propalada ausência de ontologia na obra maquiaveliana e da força ontológica espinosana, - presente, de modo desdobrado, na refinada construção da parte I da Ética, ponto fundante de sua ontologia -, alguns comentadores constatam a presença de Maquiavel até mesmo na metafísica espinosana. ${ }^{23}$ Assim, ao Florentino não restaria somente uma teoria da História, que, se confirmada, - convenha-se - não é pouca coisa. Se como quer Agnes Heller, a história como ciência principia ao tempo do Renascimento, Maquiavel encontra-se na raiz de tal invenção moderna.

Em Prússia, o primeiro registro de estudo maquiaveliano data de 1731, pela obra De Nicolao Machiavelli, autoria de Johann Friedrich Christ (1701-1756), considerada controversa, porém "capaz de suscitar amplo clamor". Após, Frederico III (1712-1786), o déspota esclarecido, elogiado por Kant pela tolerância religiosa, encomendou de Voltaire - Anti-Maquiavel ou Exame do Príncipe de Maquiavel, de 1740. Oportuno lembrar que a obra analisa capítulo por capítulo o tratado maquiaveliano, ${ }^{24}$ como fizera Innocent Gentillet, em obra acima referida, porém, sob a forma de máximas e sob outra chave de interpretação. 25

pela evangelização apostólica, milagrosa de São Bartolomeu (BACON, 1973, p. 246)." - Da noite de São Bartolomeu até a ressignificaçăo da catequese cristă junto aos indianos - como suposto, provavelmente, pelo mesmo santo - contam quarenta e seis anos...

${ }^{21}$ Conforme Luiz Carlos Montans Braga, relatório de estágio pós-doutorado, intitulado Desejo e Política: uma aproximação entre Maquiavel e Espinosa, realizado em Filosofia, na PUC-SP, 2018.

${ }^{22}$ ESPINOSA. Tratado Político. Tradução, Introdução e notas de Diogo Pires Aurélio. São Paulo: Martins Fontes, 2009, pp. 45-46. Citação do Capítulo V, parágrafo 7. Espinosa chama-o igualmente "agudíssimo florentino" no Capítulo X, parágrafo 1 ( $\left.\mathrm{p}_{.} 129\right)$.

${ }^{23}$ Para Laurent BOVE, "No que se refere a Maquiavel, o estudo dos seus textos, em relação a Spinoza, deve nos convencer do quanto o filósofo de Amsterdă é maquiaveliano, näo apenas em política, como na sua própria metafísica. Com efeito, é como se Spinoza, ao escrever a sua Ética, conduzisse o pensamento de Maquiavel do plano da política e da história ao plano de imanência da sua ontologia dinâmica. Disso decorre o uso que eu faço da noção de estratégia do conatus, segundo uma formulação que é quase um pleonasmo, porque, para mim, o conatus spinozista (e/ou o esforço que cada ser faz para perseverar em seu ser) é essencialmente (ou por natureza) estratégico. Uma estratégia paradoxall, sem finalidade nem modelo, senão que, ontologicamente falando, cada ser é sempre tăo perfeito quanto pode ser; isso significa que, no seu esforço indefinido de perseverança em seu ser, cada ser adota, a cada instante, a estratégia perfeita em função das necessidades que ele afirma e com as quais se afronta. A potência spinozista é, assim, em si mesma e por ela mesma, estratégica, isto é, maquiaveliana (BOVE, 2015, pp. 228-229)."

24 "Voglio assumermi la difesa dell'umanità contro questo mostro che la minaccia, oporre la giustizia e la ragione al crimine e al sofisma; ho tentato de esprimere le mie riflessioni sul Principe capitolo per capitolo, affinché l'antidoto seguisse immediatamente il veleno (FEDERICO II, 1987, p. 3)."

${ }^{25}$ A propósito, Federico II registra: "devo dire qualche parola a chi crede che Machiavelli descriva i principi come sono e non come dovrebbero essere: è um pensieto che è piaciuto a molti, perchè há ill sapore della satira. [...] ill libro di Machiavelli non contaminerebbe più̀ le scuole di politica, verrebbero considérate con disprezzo le contraddizioni in cui egli cade continuamente, tutti sareberro convinti che la vera politica dei re, fondata sulla giustizia, la prudenza e la bontà, è preferibile in tutti i sensi al sistema incoerente e orrendo che Machiavelli há avuto la sfrontatezza di presentare al pubblico (FEDERICO II, 1987, pp. 45)." 
Merece distinção a recepção favorável dos idealistas alemães, Hegel e Fỉchte. A reflexão hegeliana, intitulada "O 'Príncipe' de Maquiavel e a Itália", novo capítulo de a Constituição da Alemanha (A formação dos estados no resto da Europa), ${ }^{26}$ em que Hegel compara a situação política da Prússia e da Itália, presente e passada, procede para considerações acerca do Sacro-Império Romano Germânico, e trata de modo elogioso e apologético o homem Maquiavel e a obra O Príncipe. Registra: "homem que fala com tom de verdade" e sua a obra é de gênio. Para Hegel, o referido livro de Frederico II conduziu a erro de compreensão de Maquiavel. - Em verdade, Hegel objetivava a unificação da Alemanha, tomando de empréstimo o substrato da conclamada unificação da Itália, constante do Capítullo XXVI de Il Principe, e a fundação de um estado monárquico aos moldes do estado francês.

O ensaio de Fichte, "O pensamento político de Maquiavel" (Über Machiavell als Schrifesteller; und Stellen aus seinen Schriften), de 1807, publicado na revista Vesta, de Könisgberg, obteve reconhecimento imediato e repercussão continuada. Fichte inicia o estudo de Maquiave ${ }^{27}$ traçando a fortuna crítica de sua obra, como se lê na primeira parte do ensaio. E no passo de resgate do "caráter intelectual e moral do escritor", registra, sob paráfrase do Capítulo XV de Il Principe, as constatações: "Maquiavel repousa inteiro sobre a vida efetiva e a imagem dela, a história; e tudo aquilo que o mais fino, o mais abrangente entendimento e sabedoria prática da vidla e do governo são capazes de introduzir na história e, por isso mesmo, desentranhar novamente dela, ele executa exemplarmente e, como estamos inclinados a acreditar, de maneira privilegiada em relação aos outros escritores modernos de sula espécie (FICHTE, 2010, p. 19)." Ao que adita, "seu livro do Príncipe, em particular, destinava-se a ser um livro de necessidade e de ajuda para todo príncipe, em toda situação em que um deles pudesse encontrar-se, e ele, guiado particularmente pelo feitio de sua pátria e de sua época, delineia o plano com suficiente amplitude (FICHTE, 2010, p. 21)。" E arremata: "é um milagre que Maquiavel segundo o qual a estupidez bem poderia ser também um vício, e que sem dúvida acreditava que, quando se é um grande celerado, é preciso ao menos não ser ainda por cima um grande estúpido - não estivesse muito inclinado a lamentar os enganos ou a ralhar com seu opressor? (FICHTE, 2010, p. 23)."

Nas partes seguintes, Fichte reflete acerca do republicanismo e do monarquismo maquiavelianos, do paganismo, dos escritos do Florentino, da liberdade de escrita e de imprensa, interroga se a "medida política de Maquiavel ainda tem aplicação também a nosso tempo", com inflexão para a situação prussiana, desde os Discorsi chegando ao II Principe (FICHTE, 2010, pp. 25-52). E por fim, apresenta passagens dos escritos maquiavelianos (FICHTE, 2010, pp. 53-82), seguidas de "Adendo(s)", em que Fichte os comenta (pp. 57-60; 69-70; 72-73 e pp. 78-82).

Sob chave de recepção distinta das precedentes, Nietzsche, admirador e assimilador do pensamento político maquiaveliano, sobremaneira ao tratar da grande política, escapando da miúda politicagem, pondera em Além do bem e do mal. "[...] como poderia a língua alemã, mesmo na prosa de um Lessing, imitar o tempo de Maquiavel, que no seu Príncipe nos faz respirar o ar fino e seco de Florença, e só consegue expor o assunto mais sério em um indomável allegrissimo - talvez com maliciosa percepção

${ }^{26}$ HEGEL, G. W. F。, "II 'Principe’ di Machiavelli e l'Italia”, Nono Capítulo de Costituzione della Germania (La formazione degli stati nell resto d'Europe), In HEGEL, G. W. F., Scritti politici, a cura di Claudio Cesa, Torino, Einaudi, 1972, pp. 101-108.

${ }^{27}$ Torres considera que "O ensaio tem a estrutura de uma obra de divulgação (o próprio Fichte, segundo testemunhos da época, estava tendo seu primeiro contato com Maquiavel): compóe-se de uma extensa introdução, com dados biográficos, históricos e enumeração de obras, acompanhados de ocasionais observações (e apenas um capítulo diretamente interpretativo, onde se indaga 'em que medida a política de Maquiavel se aplica aos nossos tempos"); uma seleção de textos de O Príncipe, traduzidos para o alemão e comentados; e uma conclusão geral, onde se trata menos de Maquiavel que de seus leitores atuais. Mas a interpretação, a inflexão da leitura que Fichte faz de Maquiavel, permeia o texto do começo ao fim, incidindo sobre a própria tradução e o recorte dos trechos de O Príncipe que inclui. Fichte dá, com isso, um exemplo de escrever sobre um escritor político, o que significa, já, escrever sobre política e - mais ainda - escrever politicamente (TORRES, 2010, pp. 12-13)." 
artística do contraste que ousa: os pensamentos, difíceis, prolongados, duros, perigosos, e um tempo de galope e bom humor mais caprichoso. (NIETZSCHE, II, § 28, 2005, p. 33)." Em outra passagem, Nietzsche desabafa: "- Meu descanso, minha predileção, minha cura de todo platonismo sempre foi Tucídides. Tucídides e, talvez, o príncipe de Maquiavel são os mais próximos a mim mesmo, pela incondicional vontade de não se iludir e enxergar a razão na realidade - não na 'razão', e menos ainda na 'moral' ... [...] disso nada cura tão radicalmente como Tucídides (NIETZSCHE, X, § 2, 2006, p. 103)."28 Associar Maquiavel a Tucídides derivou da leitura de Burckhardt, A civilização do Renascimento em Itália, de 1860. Contudo, Nietzsche predica a leitura de Tucídides e de Maquiavel para vencer o excesso entediante de metafísica do ambiente filosófico europeu, em particular do alemão. - Maquiavel para vencer o tédio! Atualizando, para superar os politólogos norte-americanos de plantão.

Em Humano, demasiado humano, Nietzsche, ao explorar a questão do "enobrecimento pela degeneração", encerra a reflexão citando diretamente o Florentino: "Quanto ao Estado, diz Maquiavel que 'a forma de governo é de importância política deveria ser a duração, que sobreleva todo o resto, por ser bem mais valiosa que a liberdade' (NIETZSCHE, V, § 224, 2005, p. 143)." - Maquiavel mais que prezava, defendia a liberdade cívica...

Max Weber, influenciado sobretudo pelo II Principe e os Discorsi, de Maquiavel, concebeu a ética de princípios e a ética de responsabilidade, a privada e a pública, ainda que sob certa demarcação neokantiana. Além de identificar e nomear, anacronicamente, por maquiavelistas indianos, os escritos compilados por Kautilya, praticamente, trezentos anos antes de Cristo, registrados em Arthasastra ( $O$ código do poder ou Arte da guerra e da estratégia indiana). ${ }^{29}$ Em Ciência e Política, ao analisar a política indiana, Weber registra: "A literatura hindu chega a oferecer-nos uma exposição clássica do 'maquiavelismo' radical, no sentido popular de maquiavelismo; basta ler o Arthaçastra, de Kautilya, escrito ${ }^{30}$ muito antes da era cristã, provavelmente quando governava Chandragupta, comparado a esse documento, O Príncipe de Maquiavel, é um livro inofensivo (WEBER, MCMLXX, p. 117)。" - A obra dos "maquiavelistas" indianos era objeto de pesquisa de Mauricio Tragtenberg ao falecer, em $1998^{31}$

Em Itália, são relevantes as assertivas de Giambattista Vico (1668-1744), em a Ciência Nova, de 1744, à posição maquiaveliana. Explicitamente, Vico refere-se a Maquiavel no item "Da custódia das leis", em que escreveu:"a causa que produziu, para os Romanos, a mais sábia jurisprudência do mundo [...], é a mesma que fez deles o maior império do mundo; e é a causa da grandeza romana, que Políbio, demasiado genericamente, refunde na religião dos nobres, e Maquiavel, pelo contrário, na magnanimidade da plebe, e Plutarco, invejoso da virtude e da sabedoria romanas, refunde na sua fortuna, no livro De fortuna romanorum, a quem, por outras vias menos directas, Torquato Tasso escreveu sua generosa Risposta ${ }^{32}$ (VICO, 2005 e 2007, § 1103)." As alusões correspondem em a História, de Políbios, I, 3, 7, e aos Discorsi, de Maquiavel,

\footnotetext{
${ }^{28}$ Em outro lugar, Nietzsche registra: "Um modelo. O que amo em Tucídides, o que faz que o tenha em mais elevado apreço do que Platăo? Ele tem o mais amplo e despreconcebido deleite em tudo o que é típico do ser humano e dos eventos, e acha que a cada tipo corresponde um quantum de bom senso: é este que ele procura descobrir. Ele tem mais justiça prática do que Platão; não é um denegridor e diminuidor dos homens que não The agradam ou que o magoaram na vida (NIETZSCHE, Aurora, III, § 168, 2004, p. 123)."

${ }^{29}$ Conferir KAUTILYA, II Codice del Potere (Arthasastra): arte dela guerra e dela strategia indiana, a cura de Gianluca Magi, Vicenza, Il Punto d'Incontro, 2017.

${ }^{30}$ Em verdade, "escrito", para o caso, significa "compilado".

${ }^{31}$ Dentre os alemães que assimilaram e criticaram o pensamento maquiaveliano, destaque para Johann Friedrecich Christ (1701-1756), autor de De Nicolao Machiavello (1731), obra controversa, provável inspiradora de O AntiMaquiavel (1740), de Frederico II da Prússia. E também para Fichte, em Discurso à nação Alemã, de 1808, que se funda em aspectos militares de $A$ arte da Guerra, de Machiavelli. Ocorre que o Discurso findou por inspirar Carl von Clausewitz (1780-1831) na escritura de Da Guerra (Vom Griege), em que analisa táticas de guerra, a partir das guerras napoleônicas, publicada em 1832.

${ }_{32}$ Título completo da obra de Torquato Tasso, Risposta di Roma a Plutarco, nella quale reprova la sua opinione della fortuna de' romani e della fortuna e virtù di Alessandro.
} 
2, 1. Ainda no § 1109, de Ciência Nova, lê-se: "Epicuro é, de fato, refutado, pois que atribui ao acaso, como os seus seguazes, Hobbes e Maquiavel (Adunque, di fato è confutato Epicuro, che dà il caso, e di lui seguaci Obbes e Machiavello (VICO, 2005 e 2007, § 1109)." Em outra passagem, há um subtexto maquiaveliano passível de ser reconhecido na enciclopédia viquiana, escrita sob o escopo da cultura barroca: "Quando os povos se encarniçam com as armas, de modo que entre eles já têm lugar as leis humanas, o único meio poderoso para os submeter é a religião (Ove i popoli son infieriti con le armi, talché non vi abbiano più luogo l'umane leggi, l'único potente mezzo di ridurgli è la religione) (VICO, 2005 e 2007, § 177), como se lê em Maquiavel, nos Discorsi, I, 2. Contemporaneamente, Benedetto Croce cuidou do debate historiográfico-filosófico entre Maquiavel e Vico. ${ }^{33}$

Em contraposição a Vico, ao menos no tocante ao pensamento maquiaveliano, Giacomo Leopardi (1798-1837), compara Maquiavel a Xenofonte, em texto inacabado, intitulado "Para o Conto "Xenofonte e Maquiavel", de 13 de junho de 1822. Leopardi cede a palavra ao Florentino, que analisa os tempos decadentes, tão ao gosto de Leopardi, como substrato ao tema do fim do ethos antigo. Em verdade, Leopardi toma partido do realismo político de Maquiavel, ora transformado em personagem literário, contra os excessos do palavreado vazio de Xenofonte. Leopardi pensa que o tempo exigia ação política efetiva na Itália, em crise desde o Renascimento.

A propósito, Leopardi registrou: "DIRÁ MAQUIAVEL: [...] como homem de talento não demorei em tirar proveito da experiência e, tendo conhecido a verdadeira natureza da sociedade e dos meus tempos (que terão sido diferentes dos teus), não fiz como aqueles estultos que pretendem renovar o mundo com as suas obras e com suas sentenças, o que sempre foi impossível, mas aquilo que era possível eu próprio me renovei. E quanto maior foi o meu amor pela virtude (virtù) e daí quanto maiores as perseguições, os danos e as desventuras que tive de sofrer por eles, tanto mais sólida, fria e eterna foi a minha apostasia. [...] Depois, voltando escrever e a filosofar, não criei preceitos de moral, que já estava irreparavelmente abolida e destruída de fato, sabendo bem [...] que não se pode renovar o mundo; mas como verdadeiro filósofo ensinei o método de governar e de viver que entrou para sempre na moral da época e que se praticava realmente. [...] Porque fazendo profissão de escritor (e, portanto, mestre dos leitores e da vida) não enganei os homens considerados meus discípulos e, prometendolhes ensinar, não os tornei mais rudes e tolos do que antes; não lhes ensinei coisas que depois devessem desaprender; em suma, como escritor didático, tendo em vista a utilidade dos leitores, não lhes dei preceitos danosos ou falsos, mas expliquei-lhes distinta e claramente a arte verdadeira e útil: estabelecendo, não quanto ao fato mas quanto à observação dos fatos, o que é propriamente dever do filósofo e quanto às doutrinas que desta filosofia derivam, uma nova escola ou filosofia para substituir a tua socrática, contrária àquela e para durar e servir (segundo o que penso) muito mais do que ela e de qualquer outra, talvez enquanto os homens forem homens, isto é, diabos de carne. [...] realizei a obra mais útil aos homens (a quem queira bem considerar), de quantas produziu a mais estranha filantropia, ou qualquer outra qualidade humana (LEOPARDI, 1996, pp. 465-466)." ${ }^{n} 34$

A meados do século XIX, registra-se a apropriação ideológica de aspectos da obra maquiaveliana por políticos italianos, ao tempo da Unificação. $\mathrm{E}$ ao início do século

\footnotetext{
${ }^{33}$ A propósito, Barbuto registrou: "La relazione fra Vico e Machiavelli è entrata nel dibattito storiografico e filosófico sul Modemo da quando nel 1924 Benedetto Croce pubblicò sulla 'Critica' un saggio sui due pensatori (Machiavelli e Vico, poi in B. CROCE, Elementi di politica, Bari, Laterza, 1925, pp. 59-67). La relazione fra i due scrittori nasce dalle cose stesse, in quanto Vico a più ripresse nelle sue opere critica Machiavelli. In particolare, nella dedica del Del Antiquissima il f́ilosofo napoletano elogia l'amico Paolo Mattia Doria per avere composto un anti-Principe del Machiavelli e nel De Uno censura il Principe del Segretario fiorentino, stimatizzato insieme a Epicuro Hobbes Spinoza, per non avere ritenuto possible la giustizia nel affari umani. Per giunta, Vico critica Machiavelli per avere affidato la storia umana al caso e per essersi fermato alla mera constatazione del perseguimento dell'utile da parte degli homini (BARBUTO, In Trecanni, 2013, p. 286)."

${ }^{34}$ Para compreensão da relevância da literatura e da filosofia pessimista de Leopardi, conferir CARPEAUX, $\mathrm{O}$. M., "Romantismos em oposicăo", In CARPEAUX, III, 2011, pp. 1554-1561.
} 
XX, a investida paradoxal de Mussolini, como se figurasse a encarnação rediviva da figura política do "príncipe" de Maquiavel, sob leitura particularíssima, operada, conjuntamente, com a figura do Dux, presente em Da Monarchia, de Dante Alighieri, simplesmente, transfigurado em II Duce, autoproclamado condutor da Itália, ao tempo em que o festim capitalista apagava suas luzes para novos ingressos, ao início do Século passado. ${ }^{35} \mathrm{E}$ quando as luzes foram apagadas de vez, sobrou lugar somente para a Alemanha e o Japão. Na atualidade, para a China.

Contudo, a polêmica acerca do maquiavelismo e do anti-maquiavelismo, de certa forma, encerra-se com Gramsci, pela análise filosófico-política de tallhe literário realista. Em "Breves notas sobre a política de Maquiavel", Gramsci escreve: "\$1. O caráter fundamental do Príncipe é o de não ser um tratado sistemático, mas um livro 'vivo', no qual a ideologia política e a ciência política fundem-se na forma dramática do 'mito'. Entre a utopia e o tratado escolástico, formas nas quais se configurava a ciência política até Maquiavel, este deu à sua concepção a forma da fantasia e da arte, pela qual o elemento doutrinário e racional personifica-se em um condottiero, que representa plástica e 'antropomorficamente' o símbolo da 'vontade coletiva'. O processo de formação de uma determinada vontade coletiva, para um determinado fim político, é representado não através de investigações e classificações pedantes de princípios e critérios de um método de ação, mas com qualidades, traços característicos, deveres, necessidades de uma pessoa concreta, o que põe em movimento a fantasia artística de quem se quer convencer e dá uma forma mais concreta às paixões políticas (GRAMSCI, 2017,3, p. 13)."

Há na síntese gramsciana elementos redivivos da filosofia política moderna, de Espinosa e de Rousseau, além do substrato de recorrência aos teólogos políticos medievais, em movimento de recurso ao mito e à fantasia, como exigira Vico em sua concepção de História, em a Ciência Nova. E tal movimento de o mito do príncipe, desde a figura violenta do condottiero, sob a plasticidade do hábil Filósofo, estudioso de Literatura. Se após, houve curvatura para os desígnios políticos da identificação de o príncipe com sua atualização na forma de partido político, para o caso, por suposto trata-se do partido comunista. Tal recurso é relevante em vista da compreensão expandida da obra maquiaveliana. A propósito, Gramsci escreveu: " "príncipe" poderia ser um chefe de Estado, um chefe de governo, mas também um chefe político que pretende conquistar um Estado ou fundar um novo tipo de Estado; nesse sentido, a tradução de 'príncipe' em linguagem moderna poderia ser 'partido político' (Q I, 5, pp. 661-662, CC, 3, p. 225)". Ao que adita: "O moderno príncipe, o mito-príncipe não pode ser uma pessoa real, um indivíduo concreto, só pode ser vum organismo; um elemento complexo de sociedade no qual já tenha tido início a concretização de uma vontade coletiva reconhecida e afirmada parcialmente na ação. Este organismo já está dado pelo desenvolvimento histórico e é o partido político, a primeira célula na qual se sintetizam germes de vontade coletiva que tendem a se tornar universais e totais' ( $Q$ III, $13,1, p$. 1558, CC, 3, 16)."

Oportuna a reflexão gramsciana acerca do Capítulo XXVI, para o qual registrou: "A Conclusão d'O Príncipe justifica todo o livro também em relação às massas populares, que realmente esquecem os meios empregados para alcançar um fim se este fim é historicamente progressista, isto é, se resolve os problemas essenciais da época e estabelece uma ordem em que seja possível se mover, operar, trabalhar tranquilamente (QIII, 13, p. 1618, CC, 3, p. 76)." Para Gramsci, Maquiavel não é o frio técnico da política como querem Carl Schmidt e Leo Strauss, mas, o teórico da política como ação política integral. Ao fim e ao cabo, a Itália produziu três incontornáveis pensadores políticos: Dante, Machiavelli e Gramsci.

${ }^{35}$ A propósito, conferir "A definição de fascismo" e "Os dois eixos do fascismo", In BERNARDO, J., Labirintos do Fascismo. na encruzillhada da ordem e da revolta, $3^{3}$ versão, 2018, pp. 13-43 e pp. 44-69, respectivamente. 
Tempos depois, Merleau-Ponty, Lefort, Debord, estudiosos italianos, alemães e alguns norte-americanos puderam ler Maquiavel de modo independente das peias do maquiavelismo e do anti-maquiavelismo.

A recepção de Maquiavel no Brasil. Questão incontornável: por que o pensamento político brasileiro, se acaso existe, não assimilou a filosofia política de Maquiavel, dentre as de outros filósofos políticos modernos expressivos, e, por consequência, produziu um pensamento político anêmico?

Para Raymundo Faoro, o "pensamento político brasileiro, na sua origem, é o pensamento político português. (Pois) A colônia - a conquista, como se dizia nos documentos oficiais - prolonga a metrópole, interiorizada, geograficamente a partir de 1808, culturalmente em cada ato político, desde a integração da primeira à última. (Umma vez que) Entre a dinastia de Avis, conjugada ao Renascimento e à Contrarreforma, constituiu-se a nacionalidade portuguesa (FAORO, 1994, p. 23)." Contudo, se Portugal funcionou como "pórtico da Idade Moderna, não (foi) uma unidade de fixação econômica, mas agência de interesses alheios e europeus, (que) postos fora do controle da nacionalidade, explique a anomalia, [...] de uma revolução (burguesa - avant la lettre -) irrealizada (FAORO, 1994, p. 23)." À sua vez, o "Renascimento europeu, além de privilegiar a ideia de nacionalidade, com a nota tônica posta na soberania interna, fixa o contorno da ideia de liberdade", que "significa independência e autogoverno", [...], porém, "começa aí o isolamento português, imune às nascentes teorias da soberania popular, e [...] de outro lado, entra em cena a secularização da política, que se emancipou da teologia e do papado. Essa corrente não correspondia, senão que contrariava, o interesse do Reino, preocupado em assenhorear-se, com o Tratado de Tordesilhas, de metade do mundo. [...] Tal preocupação monárquica explicará, no futuro, a ausência de Maquiavel na cultura portuguesa. Tratava-se de assegurar à religião institucionalizada a preeminência política, a qual, pela via do papado, garantia a empresa marítima, protegendo-a contra as agressões dos países concorrentes. [...] O entendimento destilado em $O$ Príncipe, de que a religião era mero instrumentum regni, insinuava o predomínio secular, pelo mero uso da religião como cimento ideológico. Por isso, Maquiavel, acoimado, desde que dele se falou, de 'herege', ímpio', 'perverso' e ignorante, esperaria, para ser traduzido em língua portuguesa, o século XX, depois de universalmente consagrado (FAORO, 1994, pp. 23-24)." ${ }^{n 6}$ Portanto, Portugal permaneceu de fora do ideário do humanismo cívico renascentista, como um todo. Salvo, a arquitetura, a escultura e a pintura de Francisco D'Holanda (1517-1585), aprendidas durante a estada romana, ao convívio de artistas do círculo de Vitória Colonna, a mecenas, principalmente Michelangelo, de inspiração neoplatônica. Para D'Holanda, o caminho da arte advém da lição da natureza, considerada espelho do Criador, em movimento de ascensão até Ele.

No caso brasileiro, por hipótese, o mais emblemático pensador político nacional, sem leitura de Maquiavel, talvez seja Tavares Bastos (1839-1876), alagoano, bacharel (1858) e doutor em Direito (1859), autor de nove livros, com destaque para Os males do presente e as esperanças do futuro, de 1861, e Cartas de um solitário, de 1862. Para Morais Filho: "Nenhum pensamento foi mais coerente entre nós, das premissas às conclusões, sem nenhuma contradição, verdadeiramente inteiriço. Já no seu primeiro livro, Os Males, de 1861, apontava ele nas origens portuguesas e no regime colonial a fonte primordial de todos os nossos males. Para ele o Brasil teria sido um filho temporão de pai velho e decadente, cheio de achaques, e que só lhe teria transmitido suas mazelas. 'Portugal brilhou um dia, no século XV, e morreu para sempre.' [...] Aí a origem dos nossos males; tal metrópole, tal colônia. A idade heroica já

\footnotetext{
${ }^{36}$ Segundo BAGNO, "E sebbene ill nome di Machiavelli arrivi ad essere inserito nel 1561 pure in un Index Prohibitorum portoghese, dopo essere stato iscritto da Paolo IV nel 1559 nell'Index romano, ciò non impedì la circolazione delle sue opere fra il Seicento e il Settecento, fino alla comparsa di una traduzione nel 1760 parziale e manoscritta - del Principe, di Francisco Bernardo Holbeche, oggi conservata nella Biblioteca di Evora. [...] nell 1933 esce in Brasile uma trduzione di Ellias Davidovich [O Principe, Rio de Janeiro, Calvino Filho]; e nel 1935 esce in Portogallo una traduzione di Francisco Morais [O Principe, Coimbra, Atlântida] (BAGNO, 2013, pp. 219-220)." Para FAORO, "Pela mesma razão, a Contrarreforma encontra em Portugal campo fértil de aceitação, inquisitorialmente escoltada, agora voltada também contra as influências desnacionalizantes (FAORO, 1994, p. 24)."
} 
ficara para trás. [...] Neste contraste assenta-se todo o edifício lógico do pensamento político de Tavares Bastos. Vai ser ele uma constante em todos os momentos da sua obra (MORAIS FILHO, 1978, p. 1)." Em síntese, o Pensador se movimenta desde a "aversão ao colonialismo português, ao absolutismo, à centralização, ao ultramontanismo, ao atraso, ao nosso isolamento do mundo; (para) a criação de uma mentalidade nova, de uma política americana, baseada na liberdade e no progresso, material e moral (MORAIS FILHO, 1978, p. 12)." Vez que a doutrina liberal o orientava política e economicamente. ${ }^{37}$ - Mas, Tavares Bastos "não era livresco" 38

Em Os Males do Presente e as Esperanças do Futuro, Tavares Bastos identifica a causa dos males nacionais ao posicionar-se contra o passado colonial português, sob o absolutismo, em que o "século XVI foi o teatro do absolutismo mais depravado" (p. 29). Uma vez que "Portugal brilhou um dia, no século XV, e morreu para sempre", constatação reforçada por Camões, o agoureiro, que compreendeu haver maior louvor ao passado que às esperanças do futuro: "A pátria, não, está metida / No gosto da cobiça e na rudeza / De uma austera, apagada e vil tristeza". Assim, para o Pensador a "história interna da metrópole aclara a fisionomia da colônia" (p. 30), pois, a herança colonial deixara traços indeléveis no Brasil do século XIX como se lê na "Introdução" da obra, item "Realidade", às páginas 29 a 38. Fato consequente, o liberalismo não prosperar no Brasil, e "as grandes reformas liberais não se fazem precipitadamente" (p. 97). Roberto Schwarz nomeou o liberalismo no Brasil por "planta exótica", ao estudar a produção literária machadiana, dado o fato hediondo da escravidão, na contramão da premissa liberal do trabalho livre, dentre outras contradições próprias da civilização brasileira. ${ }^{39}$

N'Os Males, as referências nominais, que sugerem sustentação teórica à argumentação recaem sobre Marco Aurélio, Dante, Manzoni, Clermont de Tonerre, Benjamin Constant, Béranger, Stuart Mill, Washington, Lafayette, Luís Bonaparte, Bismarck, Mazzini.

\footnotetext{
${ }^{37}$ Segundo Morais Filho, Tavares Bastos pregou "sempre uma democracia, não só política e formall, mas igualmente social, pluralista e aberta a todos, baseada no mérito e na responsabilidade de cada um. [....] Publicista [...], talvez tenha sido o maior pensador político do Império, pelo conjunto de sua mensagem, pelos métodos realistas de análise, pela sua brasilidade universalista (MORAIS FILHO, 1978, pp. 25-26)."

38 "O pensador alagoano não era livresco, como virá ser mais tarde o seu grande continuador em tantos assuntos e seu confessado admirador, Rui Barbosa. A sua cultura histórica, econômica, política e jurídica é vasta, mas utilizada, ao correr da pena, sem exibições de erudiç̃̃o. [...] Os livros para Tavares Bastos representavam simples instrumentos de trabalho, importando-lhe mais o conhecimento direto das coisas e dos fatos. Colhia nos livros o que lhe interessava, pró e contra, mas sem abandonar nunca a sua linha de raciocínio e a sua convicção profunda (MORAIS FILHO, 1978, p. 12).

${ }^{39}$ Ao estudar a obra literária de Machado de Assis, pendulando entre escravidão e liberalismo, em que "o favor é a nossa mediação quase universal", Roberto Schwarz registrou: "Toda ciência tem princípios, de que deriva o seu sistema. Um dos princípios da Economia Política é o trabalho livre. Ora, no Brasil domina o fato 'impolítico e abominável' da escravidão. [...] Ao longo de sua reprodução social, incansavelmente, o Brasil põe e repõe ideias europeias, sempre em sentido impróprio (SCHWARZ, 1973, pp. 154, 151, 160)." A propósito, para Dardot e Laval, "O liberalismo é um mundo de tensões. Sua unidade, desde o princípio, é problemática. O direito natural, a liberdade de comércio, a propriedade privada e as virtudes do equilíbrio do mercado são certamente alguns dos dogmas do pensamento liberal dominante em meados do século XIX. Modificar os princípios seria quebrar a máquina do progresso e romper o equilíbrio social. Mas esse whiggismo triunfante não será o único a ocupar terreno nos países ocidentais. As críticas mais variadas florescerăo, tanto no plano doutrinal como no político, ao longo do século XIX. Isso porque em nenhuma parte, e em nenhum domínio, a 'sociedade' se deixa reduzir a uma soma de trocas contratuais entre indivíduos. A sociologia francesa não cansará de repetir isso, ao menos desde de Auguste Comte, sem mencionar o socialismo que denuncia a mentira da igualdade apenas fictícia. Na Inglaterra, o radicalismo, depois de inspirar as reformas mais liberais de assistência aos pobres e ajuda à promoção do livre-câmbio, alimentará certa contestação dessa metafísica naturalista e até estimulará as reformas democráticas e sociais a favor da maioria (DARDOT e LAVAL, 2016, p. 37)." Em verdade, Dardot e Laval abordam a "sociedade neoliberal", tomando o neoliberallismo como "a nova razão do mundo". Ocorre que - equívoco dos autores, por hipótese, reside no fato de fundarem suas críticas ao neoliberalismo, demasiadamente, em Naissance de la biopolitique, de M. Foucault e não considerarem, em nenhum momento, a crítica aguda e sumarenta de I. Mészáros ao liberalismo e ao neoliberalismo, - mesmo sem nomear o último -, exposta no Capítulo 4, "Transformações materiais e formas ideológicas", da obra Estrutura Social e Formas de Consciência: a dialética da estrutura e da histónia II, 2011, pp. 105-176. Em particular, no item 4.4 do Capítulo, "Transformação radical da superestrutura jurídica e política", pp. 149-176. E também contidas no Capítulo 3 , "Soluçôes para incontrolabilidade do capital, do ponto de vista do capital", particularmente, no item 3.1., "As respostas da economia política clássica", em Para além do capital, 2011, pp. 133-140.
} 
Ao passo que as Cartas de um Solitário contêm três séries e apêndices. Os temas analisados nas séries são: "Organização administrativa", "Ensino religioso"; "Africanos livres e tráfico de negros" e "As leis de navegação. O comércio costeiro. A franquia dos grandes rios. Questão do Amazonas. Comunicações diretas entre as duas Américas." Os apêndices, de certa forma, sintetizam o que fora tratado, na parte anterior. Em verdade, trata-se de uma combinatória de reforma política e de possibilidades práticas de mudanças. Na obra, aparecem referências nominais a Colbert, Montesquieu, Bentham, Gervinus, Tocqueville, Lammenais. E também a políticos como Guizot, Richelieu, Cavour, ao publicista Justiniano José da Rocha, ao papa Gregório XVI, lembrados por algumas de suas sentenças mais conhecidas ou figuras de seus pensamentos. Em ambas obras não há remissão aos pensadores clássicos da filosofia política moderna: Maquiavel, Hobbes, Espinosa, Locke, Rousseau, Kant, "Pais Fundadores" e, no limite, Hegel.

Se o genuíno pensamento de Maquiavel não adentrou o imaginário político brasileiro de forma efetiva, em compensação na literatura, Machado de Assis refere-se ao Florentino em ao menos três contos. Em "Valério", de 1875, ao caracterizar o coronel Borges registra: "A sua principal paixão era a política; era esse verdadeiro pão cotidiano que ele pedia a Deus com heroica humildade. Se lhe tirassem a política do mundo, o mundo ficaria ermo. A política era para ele o sol do mundo moral, quando a política desaparecesse começaria a morte. [...] Não nos enganemos, entretanto. A política do coronel não existe nos livros de Montesquieu nem Maquiavel; tinha outros códigos; a outras leis obedecia. A política do coronel começava no subdelegado e acabava no coronel (MACHADO de ASSIS, II, 2015, p. 1264)." Em "A Teoria do Medalhão", de 1881, o pai encerra as sugestões ao fillho Janjão acerca do que fazer na vida, em vista de possível projeção social e vida mansa de medalhão, com a tirada: "Meia-noite? Entras nos teus vinte e dois anos, meu peralta; estás definitivamente maior. Vamos dormir, que é tarde. Rumina bem o que te disse, meu filho. Gulardadas as proporções, a conversa desta noite vale o Príncipe de Machiavelli. Vamos dormir (MACHADO de ASSIS, II, 2015, p. 267)." Por fim, em "Dona Benedita", de 1882, à caracterização da personagem Eulália, o narrador escreve que, dada uma reflexão sinuosa, a "moça era profundamente maquiavélica (MACHADO DE ASSIS, III, 2015, p. 289)。:40

Contudo, há que se destacar a obra Machiavel e o Brasil, de Octávio de Faria, de 1931, considerada literatura de combate anti-Vargas. Obra singular e pioneira, reeditada em $1933^{41}$ depois desaparecida. Porém, há uma tentativa de depreciar Maquiavel, sua vida pessoal, se posta em comparação com a de atores políticos como "um Cromwell, um Mazarino, um Olivares, um Pombal, um Bismark, um Cavour, um Mussolini (FARIA, 1933, p. 31)." (Sic). Em um capítulo intitulado "Intermezzo Mussoliniano", se lê: "Mussolini é, em traços geraes, o homem com quem Machiavel sonhou [...] Mussolini, o grande homem, o indivíduo de excepção, cheio de "virtù' e protegido da 'fortuna' que logo chamaria 'o salvador da Itália', 'o redentor' (FARIA, 1933, p. 117)."

A "II Parte" do livro, intitulada "O caso brasileiro", com remissões a filósofos modernos, como Rousseau, opera a leitura pessimista do Brasil, na vaga, dentre outros, de Paulo Prado, em Retrato do Brasil, cujo objetivo seria, em última instância, o de alvejar a política de Vargas. O livro de Faria, para a segunda edição de 1931, recebeu uma resenha crítica sutilíssima, assinada por Sérgio Buarque de Holanda, de 1933, em que elogia a pessoa e fustiga severamente o ensaio (HOLANDA, 1996, pp. 248-250). estudado por Maria Tereza

\footnotetext{
40 "Em ensaio publicado no número 87 (abr-jun. 2016) da Revista Brasileira, editada pela Academia Brasileira de Letras - entre a divulgação de recentes achados literários machadianos -, foi indicada a existência de uma colaboração supostamente perdida, que Machado de Assis deu ao número especial do jornal ítalo-brasileiro II Cosmopolita (à época intitulado apenas Cosmopolita), de 20 de setembro de 1884. A publicação comemorava o $14^{\circ}$ aniversário da unificação italiana após a entrada das tropas do exército italliano em Roma, o que ocorreu para a queda do poder temporal do papa Pio IX (RISSATO, 2016, p. 1)." A página 3, de Cosmopolita encontra-se estampada a reflexão machadiana: "Cada cousa tem o seu tempo. O que estava no coração de todo italiano, o que Maquiavel insinuava aos Médici, só se pode fazer neste século, depois que a Itália aprendeu durante na escola da servidão. - A melhor liberdade é a que mais custa (MACHADO DE ASSIS, por RISSATO, 1884)." O que mostra a atenção do Literato à obra maquiaveliana mais conhecida. e ao destino da Itália, cumprido antes tarde.

${ }^{41}$ FARIA, Octávio de, Machiavel e o Brasil, 2a edição, Rio de Janeiro, Civillização Brasileira, 1933.
} 
Sadek, em Machiavel, Machiavéis: a tragédia octaviana, de 1978. Do estudo, distingue-se o Capítulo IV, "Octávio de Faria - mergulho em várias correntes ideológicas" (SADEK, 1978, pp. 113-189). - Após, fez-se uum véu de silêncio.

Segundo Alberto Venâncio Fillho, a imagem de Maquiavel melhorou, em parte, com Guerreiro Ramos, que por dever de ofício, afirmou que o preconceito contra aquele Pensador era representativo de uma jeunesse dorée -, de um ponto de vista ainda conservador (VENÂNCIO Fo, 1981, p. 54). Melhores enfoques, mais lúcidos, somente com Hermes Lima, Cândido Mota Filho, Afonso Arinos de Melo Franco, Marcílio Marques Moreira e, no limite, Mauricio Tragtenberg. Venâncio Filho registrara durante Seminário da UnB, 1981: "A messe maquiaveliana do Brasil é paupérrima, realmente desprimorosa, e não condiz com o padrão de cultura universitária que desejamos ostentar (VENÂNCIO, P. 56)." O Professor parece parafrasear a constatação de Otto Maria Carpeaux, em Livros sobre a mesa: "a bibliografia moderna sobre Maquiavel é imensa; menos em língua portuguesa".

Como resultado da ausência de estudos sistemáticos e de incorporação do universo maquiaveliano ao pensamento político brasileiro - se acaso existe, como inquiriu Raymundo Faoro (FAORO, 1994) - claudica desordenado. Afinal, talvez a mais importante invenção teórico-prática para os hhorizontes políticos brasileiros seja a ideia de conciliação, gestada e parida pelo Gabinete Paraná, em 1842, porém distante três sécullos do pensamento do Florentino. - Infeliz invenção, que não explicita nem assimila o conflito social, natural, perpetuando as aparências da ordem sócio-política, por mais contradições e fissuras que contenha.

Tempos melhores para os estudos maquiavelianos em solo pátrio se sucedem desde 1956, ao tempo em que o diplomata Lauro Escorel lançou Introdução ao Pensamento Político de Maquiavel. Ultimamente, tais estudos encontram-se consolidados, com artigos em revistas científicas e coletâneas acerca do pensamento de Maquiavel, derivadas de pesquisas acadêmicas sistemáticas na forma de teses e de dissertações. - Para não escapar à metáfora orgânica, tão cara a Maquiavel: ainda é tempo de plantar sementes maquiavelianas - aquelas de explicitar as contradições sociais e transformá-las em instituições - ao pensamento político brasileiro, antes que escureça o dia e anoiteça.

\section{Referências}

BACON, F., Nova Atlântida, tradução José Aluysio Reis de Andrade, São Paulo, Abril Cultural, 1973. (Coleção "Os Pensadores"). , Nueva Atlántida, edición Emilio García Estébanez, Madrid, Akal, 2006. , Ensaios, tradução Álvaro Ribeiro, 3a edição, Lisboa, Guimarães, 1992.

BAGNO, S., "Il Principe nell'area luso-brasiliana", In Il Principe di Niccolò Machiavelli e il suo tempo, 1513-2013, a cura di Alessandro Campi et alii, Roma, Treccani, 2013, pp. 219220 .

BARBUTO, G. M., "Vico e Machiavelli", In Il Principe di Niccolò Machiavelli e il suo tempo, 1513-2013, a cura di Alessandro Campi et alii, Roma, Treccani, 2013, pp. 286-289.

BARTHAS, J., "Appendice 1 - Coda. Moments de la fortune de la sentence machiavelienne. Francis Bacon, Georges Berkeley, Ferdinando Galiani", In L'Argent n'est pas le nerf de la guerre: essai sur une prétendue erreur de Machiavel, Rome, École Française de Rome, 2011, pp. 430-440.

BERNARDO, J., Labirintos do Fascismo: na encruzilhada da ordem e da revolta, 3 a versão, 2018. (Primeira edição, Afrontamento, Porto, 2003. Segunda e terceira, edições particulares). 
BORRELLI, G., "Agostino Nifo e il plagio del Principe", In Il Principe di Niccolò Machiavelli e il suo tempo, 1513-2013, a cura di Alessandro Campi et alii, Roma, Treccani, 2013, pp. 271-273.

BOVE, L. "Entrevista com Laurent Bove", tradução Leon Farhi Neto e Monique Farhì, In Cadernos Espinosanos, n. 33, jul dez 2015, pp. 223-246. Acessado pelo link http://www.revistas.usp.br/espinosanos/article/view/108807/107235, dia 03 de maio de 2019.

CAPATA, A., "I Ghiribizzi al Soderini. un'anticipazione del Principe?", In Il Principe di Niccolò Machiavelli e il suo tempo, 1513-2013, a cura di Alessandro Campi et alii, Roma, Treccani, 2013, pp. 97-100.

CARPEAUX, O. M., História da Literatura Ocidental, volume III, São Paulo, Leya, 2011.

CIAPETTI, R. (a cura di), Atti del Convegno Internazionale su II Pensiero Politico di Machiavelli e la sua fortuna nel mondo. SanCasciano - Firenze, 28-29 settembre 1969, Firenze, Pallazo Strozzi Firenze, Istituto Nazionale di Studi sul Rinascimento, 1972.

DARDOT, $\mathbb{P}$; LAVAL, C., A Nova Razão do Mundo: ensaio sobre a sociedade neoliberal, tradução Mariana Echalar, São Paulo, Boitempo, 2016.

DIDEROT e d'ALEMBERT, "Política", In Enciclopédia, ou Dicionário razoado das ciências, das artes e dos ofícios, volume 4, tradução Maria das Graças de Souza et alii, São Paulo, Unesp, 2015.

DIONISOTTI, Carlo, Machiavellerie: Storia e fortuna di Machiavelli, Torino, Einaudi, 1980 .

ESCOREL, L., Introdução ao Pensamento Político de Maquiavel, Brasília, UnB, 1979.

FAORO, R., Existe um Pensamento Político Brasileiro? São Paulo, Ática, 1994.

FARIA, O. de, Machiavel e o Brasil, 2a edição, Rio de Janeiro, Civilização Brasileira, 1933.

FEBVRE, L. O problema da incredulidade no século XVI: a religião de Rabelais, tradução Maria Lúcia Machado, São Paulo, Cia. das Letras, 2009.

FEDERICO II, L'Antimachiavelli, a cura di Nada Carli, Pordenone, Edizioni Studio Tesi, outobre 1987. (Tradução da edição francesa, cujo título original: Antimachiavel ou examen du Prince de Machiavel).

FICHTE, J. G., Pensamento Político de Maquiavel, tradução Rubens Rodrigues Torres Filho, São Paulo, Hedra, 2010.

1981. Machiavel et autres écrits philosophiques et politiques de 1806-1807. Paris, Payot,

FRAJESE, V., "Index librororum prohibitorum", In Machiavelli. Enciclopedia Machiavelliana, vol. II, a cura di Gennaro Sasso, Roma, Treccani, 2014, pp. $12-17$.

GENTILLET, I, Anti-Machiavel (1576), Genebre, Libraire Droz, 1968. (Organizado por C. Edward Rathé, conforme a edição de 1576).

GILBERT, F., Machiavelli e il suo tempo, traduzione Alda de Caprariis e Gustavo Gozzi, Bologna, II Mulino, 1991.

GRAMSCI, $\mathbb{A}_{n}$ Cadernos do Cárcere, volume 3, 8a edição, tradução de Luiz Sérgio Henriques, Marco Aurélio Nogueira e Carlos Nelson Coutinho, Rio de Janeiro, Civilização Brasileira, 2017.

Quaderni del Carcere, 4 volumes, a cura di Valentino Gerratama, Torino, Einaudi, 2014. 
HEGEL, G. W. F., Scritti politici, a cura di Claudio Cesa, Torino, Einaudi, 1972.

HOLANDA, S. B. de, "Maquiavel e o sr. Otávio de Faria", In O Espirito e a Letra: estudos de crítica literária, 1920-1947, vol. I, São Paulo, Cỉa. das Letras, 1996, pp. 248-250.

"A Filosofia de Machado de Assis", In , O Espírito e a Letra: estudos de crítica literária, 1920-1947, vol. I, São Paulo, Cia. das Letras, 1996, pp. 305-312.

KAUTILYA, Il Codice del Potere (Arthasastra): arte dela guerra e dela strategia indiana, a cura de Gianluca Magi, Vicenza, Il Punto d'Incontro, 2017.

LARIVAILLE, P., "Nifo, Agostino", In Machiavelli. Enciclopedia machiavelliana, a cura di Gennaro Sasso, Roma, Treccani, s.d., pp. 234-238.

LARIVAILLE, P. et PERNET-BREAU, S. Une réécriture du Prince de Machiavel. Le De regnandi peritia de Agostino Nifo, Paris, 1987. (Reimpression d'Agostino Nifo, De regnandi peritia, Naples, 1523 , avec as traduction française).

MACHADO de ASSIS, J. M., Obra Completa, vol. II, São Paullo, Nova Aguilar, 2015. (Contos).

MACHIAVELLI, No, "Istorie Fiorentine e altre opere storiche e politiche", In

Opere, a cura di Alessandro Montevecchi, volume secondo, Torino, UTET, 1986.

Torino, UTET, 1984.

"Lettere", In

Opere, a cura di Franco Gaeta, volume terzo,

MAQUIAVEL, N., O Príncipe, tradução Diogo Pires Aurélio, São Paulo, Editora 34, 2017. (edição bilíngue).

MARCHAND, J-J., Niccolò Machiavelli: I primi scritti politici (1499-1512): nascita di un pensiero e di uno stile, a cura di Rino Avesani, Guiseppe Billanovich e Giovanni Pozzi. Padova: Antenore, 1975.

MARLOWE, C. A Trágica História do Doutor Fausto - E a História do Doutor João Fausto de 1587: O Nascimento de uma Tradição Literária, tradução Luís Bueno, Caetano W. Galindo e Mario Luiz Frungillo, Cotia, Campinas, Ateliê / Unicamp, 2018.

MÉSZÁROS, I., A estrutura social e formas de consciência: a dialética da estrutura e da história, Vol. II, tradução Rogério Bettoni, São Paulo, Boitempo, 2011.

Para além do capital: rumo a uma teoria da transição, tradução Paulo Cezar Castanheira e Sérgio Lessa, São Paulo, Boitempo, 2011.

MONTANS, L. C. B., Desejo e Política: uma aproximação entre Maquiavel e Espinosa, relatório de estágio pós-doutorado em Filosofia, realizado na PUC-SP, 2018.

NIETZSCHE, F. Além do bem e do mal: prelúdio de uma filosofia do porvir (1885-1886), Cia. das Letras, 2005.

Humano, demasiado Humano, tradução Paulo César de Souza, São Paulo, Cia. das Letras, 2005a.

Crepúsculo dos Ídolos ou como se filosofa com o martelo, tradução Paulo César de Souza, São Paulo, Cía. das Letras, 2006.

Aurora: reflexões sobre os preconceitos morais, tradução Paulo César de Souza, São Paulo, Cia. das Letras, 2004.

PEDULLÀ, G. "Prima del Principes la tradizione umanistica degli specula principum", In Il Principe di Niccolò Machiavelli e il suo tempo, 1513-2013, a cura de Alessandro Campi et alii, Roma, Treccani, 2013, pp. 81-89. 
PETRINA, A., "Machiavelli in Inghilterra e Scozia: il primo secolo del Principe in lingua inglese", In Il Principe di Niccolò Machiavelli e il suo tempo, 1513-2013, a cura de Alessandro Campi et alii, Roma, Treccani, 2013, pp. 186-194.

PIERRE, M. M. S., Nicolau Maquiavel: filósofo e político confrontado, Vitória, Multiplicidade, 2005.

POCOCK, J. G. A., Il Momento Machiavelliano: Il pensiero fiorentino e la tradizione repubblicana anglosassone. Il pensiero politico fiorentino, vol. I, traduzione Alfonso Prandi, Bologna, Il Mulino, 1980.

Il Momento Machiavelliano: Il pensiero fiorentino e la tradizione repubblicana anglosassone. La "repubblica" nel pensiero político anglosassone, traduzione Alfonso Prandi, Bologna, Il Mulino, 1980.

PROCACCI, G., Machiavelli nella cultura europea dell'età moderna, Bari, Laterza, 1995.

REIS, N. H. N. dos, A recepção maquiaveliana em solo britânico: David Hume, leitor de Maquiavel, relatório do estágio de pós-doutorado em Filosofia, PUC-SP, 2017.

RIDOLFI, R., Biografia de Nicolau Maquiavel, tradução Nelson Canabarro, São Paulo, Musa, 2003.

SADEK, M. T. A., Machiavel, Machiavéis: a tragédia octaviana, São Paulo, Símbolo, 1978.

SCHWARZ, R。 "As ideias fora do lugar", In Estudos Cebrap, n. 3, São Paulo, Cebrap / Brasileira de Ciências, janeiro 1973, pp. 149-161.

SÉNECA, L。A., Carta a Lucillio, tradução I. A. Segurado e Campos, Lisboa, Calouste Gulbenkian, 2004.

SÊNECA, L. A., Tratado sobre a Clemencia (De Clementia), tradução Ingeborg Braren, Petrópolis, Vozes, 1990. ("Clássicos do Pensamento Político", vol. "Sêneca / Salústio).

SENELLART, M., As Artes de Governar. do regimen medieval ao conceito de governo, tradução Paulo Neves, São Paulo, 34, 2006.

TORRES FILHO, R. R. "Apresentação", In FICHTE, J. G。, Pensamento Político de Maquiavel, tradução Rubens Rodrigues Torres Filho, São Paulo, Hedra, 2010, pp. 9-14.

VENÂNCIO FILHO, A., "Notas sobre Maquiavel e o Brasil", In BATH, S. et alii, Maquiavel: um seminário na Universidade de Brasilia, Brasília, UnB, 1981, pp. 45-57.

VICO, G., Ciência Nova (1744), tradução Jorge Vaz de Carvalho, Lisboa, Calouste Gulbenkian, 2005. _—_ "Princìpi di Scienza Nuova" (1744), In Opere, a cura di Andrea Battistini, Milano, Arnoldo Mondadori, 2007.

WEBER, M., Ciência e Política: duas vocações, tradução Leonidas Hegenberg e Octany Silveira da Mota, São Paulo, Cultrix, MCMLXX.

Doutor em Educação (UNICAMP, 1996)

Professor Titular do Departamento de Filosofia da PUC-SP

Pós-Douitorado em Filosofia (PUCPR)

Email: valverde@pucsp.br 